\title{
Design Challenge of Converting Thirupperumthurai Dumpsite Quarry to a Landfill Bioreactor
}

\author{
Department of Agricultural Engineering \\ Faculty of Agriculture \\ University of Peradeniya, Sri Lanka
}

S.A.D.N. Senevirathne, B.F.A. Basnayake, A.S.H. Chandrasena and N.P. Rathnayake ${ }^{1}$

\begin{abstract}
The poor disposal practices of the Batticaloa Municipal Council (BMC) at the Thirupperumthuai abandoned gravel quarry are causing environmental problems. North East Coastal Community Development Project (NECCDEP) with collaboration of Provincial Council and BMC accepted to rehabilitate the dumpsite quarry and establish proper solid waste management system in Thirupperumthurai as a sustainable solution. The Solid Waste Management Research Unit (SWMRU) of the University of Peradeniya has developed technologies that can be adapted to dryer climatic conditions.
\end{abstract}

The intention of the project was to construct an above ground landfill bioreactor on a firm ground above the flood level on the quarry with old waste fill considering $30 \%$ settlement. The area of the quarry is $11715 \mathrm{~m}^{2}$. Average depth is $5 \mathrm{~m}$. Soil permeability near to housing is $50 \times 10^{-5} \mathrm{~m} / \mathrm{s}$ and $1 \times 10^{-8} \mathrm{~m} / \mathrm{s}$ for other areas of clayey soils.

The width of the landfill is $55 \mathrm{~m}$ and total extent is $11,115 \mathrm{~m}^{2}$. The design capacity of the lanfill is 38,300 tonnes for three years. The expected quality of leachate emissions from old wastes is initially around $3500 \mathrm{mg} / \mathrm{l} \mathrm{BOD}$ and would reduce to $1000 \mathrm{mg} / \mathrm{l} \mathrm{BOD}$ after 100 days. Two biofilm composite liners will prevent leachate contamination from old and new wastes. The leachate treatment requirement is $28 \mathrm{~m}^{3} /$ day for four months in a constructed wetland of $56 \mathrm{~m}^{2}$ with an effective depth of $0.5 \mathrm{~m}$ to bring the BOD to less than $400 \mathrm{mg} / \mathrm{l}$ within a day. Irrigation requirement of the landfill bioreactor is $220 \mathrm{~m}^{3} /$ day and envisaged to store a larger portion in the old waste fill and pond waters.

\section{INTRODUCTION}

Batticaloa Municipal Council (BMC) serves many sectors such as industrial, agricultural and health over an extent of $79.09 \mathrm{~km}^{2}$ with a population of 84,000 . Total waste generation is 60 80 tonnes and BMC collects approximately 40-45 tonnes of wastes/day. The lacking of a proper disposal facility for wastes generated in the city is causing enormous environmental and socio-economic problems with the poor disposal practices at an abandoned quarry at Thirupperumthuai.

Unfortunately, the BMC has minimum control over the dumpsite due to lack of resources, resulting in frequent fires and scattered wastes in many parts of the dumpsite. Spilling of leachate in rainy seasons and groundwater contamination throughout the year have continued for many years.

1 Department of Earth Resource Engineering, Faculty of Engineering, University of Moratuwa 
It is likely to have methane $\left(\mathrm{CH}_{4}\right)$ emission. Air pollution is made worse with the activities of scavengers burning wastes to recover other non-combustible materials. Thus, BMC envisages the establishment of an Integrated Solid Waste Management (ISWM) system which will prevent or minimize existing social and environmental impacts.

The Solid Waste Management Research Unit (SWMRU) of the University of Peradeniya has developed technologies that can be adapted to dryer climatic areas of the country such as Batticaloa. Recognizing the potential and technological advantages of these innovations, North East Coastal Community Development Project (NECCDEP) in collaboration with the Provincial Council, wanted to develop a sustainable solution for BMC to rehabilitate the dumpsite quarry and establish a proper solid waste management system in Thirupperumthurai.

The NECCDEP made considerable efforts to find alternate sites for the integrated system, since the carrying capacity of the quarry is becoming less and less, day by day. Even if another site is available, the wastes disposed in the quarry are polluting the surroundings habitats, particularly the wells. The estimation of pollution is more than fifteen more years. Therefore, the design challenge is to rehabilitate the existing dumpsite and construct landfill bioreactors. Thus, the wastes already decomposing in the quarry dump should be removed and disposed over a suitable liner system rather than importing soil from elsewhere. Both the rehabilitation of dumpsite and constructing landfill bioreactors in dry climatic conditions with cyclonic weather conditions necessitated novel design approaches that required validation. Therefore this paper highlights the challengers with well defined design criteria while providing assured solutions for developing a sustainable landfill system.

\section{MATERIALS AND METHODS}

In order to select the best technology to rehabilitate and establish environmentally sound disposal system, base data collection and preliminary estimations were carried out for the Thirupperumthurai final disposal site. Following activities and estimations were used in the process of designing the solid waste disposal facility.

\section{Land survey}

The land was contour surveyed by a registered licensed surveyor with 0.5 meter intervals within the boundary of the site. During the survey, area and the depth of the abandoned gravel quarry were determined with the information gathered from the surrounding people and the Batticaloa MC staff during the formal and informal discussions.

\section{Geological and hydrological survey}

Using five boreholes, soil type distribution and thicknesses were estimated by Earth Resource Engineering Department of University of Moratuwa. Surface water drainage patterns, ground and surface water level fluctuations, groundwater quality and availability, ground stratification, permeability and porosity were estimated during the study. 


\section{Waste quantification in the disposal site}

The existing waste was quantified using time, daily average waste collection, degree of combustion and settlement assumptions.

\section{Waste collection data in Batticaloa MC area}

It is important and essential to know the waste generation and collection information to decide on the appropriate technology for the final disposal facility. Therefore, required data was obtained from the Batticaloa MC.

\section{Estimation of waste settlement}

The intention of the project was to construct an above ground landfill bioreactor and thus the filling of quarry with old waste to make a firm ground above the maximum flood level for the landfill bioreactor. Therefore, settlement of old/partially degraded waste was estimated using the lysimeter simulation studies carried out at University of Peradeniya and one dimensional consolidation model estimations by Gunawardana et al. (2008). The primary and long term secondary settlement is given by the following expression (Qian et al., 2002);

$$
\Delta H=\Delta H_{c}+\Delta H_{\alpha}
$$

Where; $\Delta H=$ total settlement of waste, $\Delta H_{c}=$ primary settlement and $\Delta H_{\alpha}=$ longterm secondary settlement

Since the existing waste is already decomposed, primary settlement was not considered for the settlement calculation. Therefore,

$$
\text { Long-term secondary settlement } \Delta H_{\alpha}=C_{\alpha}^{\prime} \cdot H_{o} \cdot \log \frac{t_{2}}{t \text {. }}
$$

Where; $\quad C_{\alpha}^{\prime}=$ modified secondary compression index, $H_{o}=$ initial waste height, $t_{1}=$ starting time of the long-term secondary settlement time period and $t_{2}=$ ending time of the long-term settlement time period

\section{Estimation of leachate generation and quality and treatment requirements}

The leachate generation was estimated using Hydrologic Evaluation of Landfill Performance (HELP) model and the quality of the leachate of old waste was predicted using the landfill simulation studies at the University of Peradeniya (Gunawardana et al., 2008). The leachate treatment requirement was estimated with the leachate generation, quantity and the water balance of the landfill bioreactor.

\section{Estimation of drainage requirement}

The surface water drainage pattern, evapotranspiration (ET), seepage and the rainfall were the key data used in determining the drainage requirement. The general slopes of the site were used as essential criteria for designing the drainage system. The rainfall pattern and the 
irrigation requirements for the landfill bioreactor were considered for the water storage requirement estimation.

\section{Estimation of irrigation requirement}

The irrigation of the landfill bioreactor is important to maintain the required water balance for the optimum microbial activities. The parameters of leachate generation and recirculation, ET, rainfall, seepage and water requirement for the landfill bioreactor were used for this estimation.

\section{RESULTS AND DISCUSSION}

\section{Land survey}

The land survey is important for designing of the drainage, cut and fill of soil and layout of the project. The extent of the final disposal site is $40732 \mathrm{~m}^{2}$. The waste filled area is 11685 $\mathrm{m}^{2}$ and the area of the gravel quarry is $11715 \mathrm{~m}^{2}$. Average depth of the quarry is $5 \mathrm{~m}$.

\section{Geological and hydrological survey}

The sand content in topsoil was higher and larger at the higher elevation. The soil was showing uniform distribution within $0.3-0.6 \mathrm{~m}$ and the propagation of gravel beginning. Near to the housing, the permeability was $50 \times 10^{-5} \mathrm{~m} / \mathrm{s}$ and $1 \times 10^{-8} \mathrm{~m} / \mathrm{s}$ for other areas of clayey soils.

The surface water flow was towards the lagoon situated $300 \mathrm{~m}$ away. In the dry season, stagnation of water is only in the deeper part of the quarry. In the rainy season, stagnant water bodies are common and large extent of land gets flooded with a $0.3 \mathrm{~m}$ flow even across the road. The main reason for the flooding is due to a single narrow culvert for the entire catchment. In the rainy season, ground water level rises on an average to $1 \mathrm{~m}$ below the surface in most of the shallow wells and some overflow with heavy rains. The groundwater levels fluctuate in between 3 to $4 \mathrm{~m}$ during the dry season from April to September and other dry spells.

\section{Waste quantification in the disposal site}

The Table 1 gives the assumptions and the quantities of waste remaining in the disposal site.

\section{Table 1. Waste quantity in the disposal site}

\begin{tabular}{lrr}
\hline Narration & Quantum & Units \\
\hline Collection and disposal rate average over 15 years & 30 & MT/day \\
Maximum quantity disposed for 15 years & 162,000 & MT \\
$1 / 2$ combustion throughout filling & 81,000 & MT \\
$1 / 3$ settlement due to decomposition & 54,000 & MT \\
Estimated volume of fill & 67,500 & $\mathrm{~m}^{3}$ \\
Volume of quarry & 104,525 & $\mathrm{~m}^{3}$ \\
Volume of occupancy with filled wastes & 64 & $\%$ \\
\hline
\end{tabular}

Note: Average Density variation from $400-1200 \mathrm{~kg} / \mathrm{m}^{3}$ on an average $0.8 \mathrm{MT} / \mathrm{m}^{3}$ for $50 \%$ combustion 


\section{Waste collection data in Batticaloa MC area}

The estimated per capita waste generation was $0.833 \mathrm{~kg} /$ day within the BMC limits. The total daily waste generation in the area is 60-80 tonnes, but only 35-40 tonnes are collected. Biodegradable fraction of the waste collected in the BMC was $54 \%$ of which $45 \%$ is short term biodegradable and the rest is long-term biodegradable.

\section{Estimation of waste settlement}

The understanding of long-term landfill settlement is very important for landfill designing and its ultimate reuse. After closure, the MSW landfills are often associated with large uneven settlements as a result of the biodegradation processes of organic matter across the landfill (Shariatmadari and Mansouri, 2008). In this case, the intension is to construct an above ground landfill bioreactor on the filled quarry (Basnayake et al., 2005). One of the design criteria was to use old waste as a fill material to make a firm ground above the maximum flood level. It required thorough understanding and estimations, since the landfill could undergo submergence with the settlement. According to the lysimeter simulation studies carried out at University of Peradeniya by Gunawardana et al., in 2008, the biologically pretreated solid waste settlement was much lower than the untreated solid waste. Therefore, according to the calculations $30 \%$ settlement over three years was taken into consideration in designing of the base fill with old wastes. Also it could compact to higher densities and the stabilization would be within a shorter period. Thus the filling of quarry with old waste is a better solution to rehabilitate disposal sites and it is cost effective than importing large quantities of soil to the site from elsewhere.

\section{Estimation of leachate generation and quality and treatment requirements}

The expected quality of leachate emissions from old wastes, using as fill materials is initially around $3500 \mathrm{mg} / \mathrm{L}$ BOD and would reduce to $1000 \mathrm{mg} / \mathrm{L}$ BOD after 100 days. These results were obtained from simulation experiments. The values could be more than double $(10,000$ $\mathrm{mg} / \mathrm{L}$ BOD) during dry spells. These values obtained during a landfill pretreatment simulation study conducted on MSW compost at the University of Peradeniya (Gunawardane et al., 2008).

\section{Estimation of drainage requirement}

The present system of surface runoff is inadequately constructed and it drains through number of landmasses and some of them have houses and finally going through a narrow culvert over to the other side of the road. The estimated surface runoff of the northeast part of the site amounted to $0.6 \mathrm{~m}^{3} / \mathrm{s}$. The quantity of water draining from the roofs and other surfaces worked out to be $0.28 \mathrm{~m}^{3} / \mathrm{s}$ from a maximum storm of $600 \mathrm{~mm} / \mathrm{hr}$. The predicted runoff from the pond for the maximum intensity derived to be $3.1 \mathrm{~m}^{3} / \mathrm{s}$. Thus, the total flow through the culvert would be $3.98 \mathrm{~m}^{3} / \mathrm{s}$.

\section{Estimation of irrigation requirements}

Water scarcity is a common occurrence for Thiruperumthurai area. Thus, the establishment of a water supply and purification plant system for drinking and washing water purposes is essential and the estimated requirement is $4000 \mathrm{~L} /$ day. Irrigation water and moisture required for anaerobic digestion in the landfill bioreactor is estimated to be $220 \mathrm{~m}^{3} /$ day. In addition, the composting plant would need $4000 \mathrm{~L} /$ day to irrigate the system on every dry day. The 
water requirement for landscaping assumed to be $10 \mathrm{~m}^{3} /$ day. Thus, the total water requirement, except the drinking water would be $234 \mathrm{~m}^{3} /$ day and it is the maximum envisaged.

\section{The design of landfill facility}

The decision of the BMC and NECCDEP after understanding the site conditions and the available technologies was to construct a landfill bioreactor for rehabilitation and future disposal of solid waste. In order to meet the design challenge of a landfill bioreactor in a selected site, it was necessary to develop a set of design criteria to meet the requirements of site specificity and available technologies. It was imperative to maintain the required design parameters and standards of classical landfills. In fact, the quarry cannot be used as an engineered or sanitary landfill without adequate fill materials to maintain the landfill above the water table and the estimated highest water table is at a level much above the bottom of the quarry, see section of the existing site in Fig. 1.

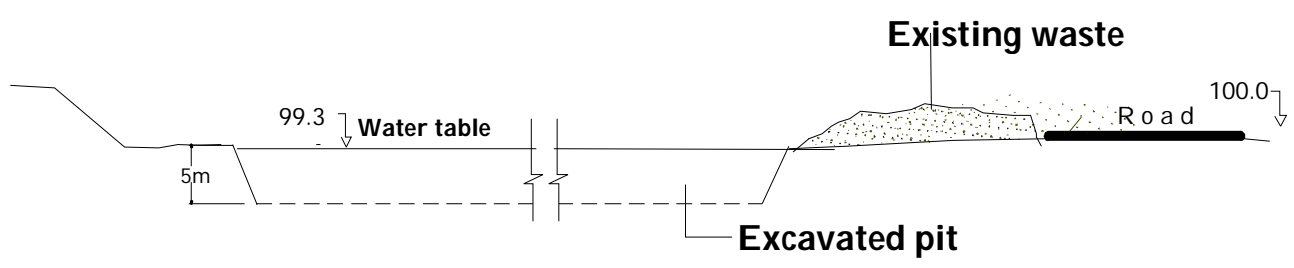

Fig. 1. Sectional view of the existing site

Under submerged and water logged conditions, there are two options namely; adequate soil filling or using the concept of engineered low-lying landfill (ELLL) with waste filling for constructing the sanitary landfill above the maximum level of water table. In order to construct a sanitary landfill, a high content of soil is required. The estimated quantity is 13,320 tonnes. Once the soil filling is completed, it will enable to lay a high density polyethylene (HDPE) liner with at least $150 \mathrm{~mm}$ thick clay layers on top and bottom of the liner that are required and recommended for preventing damage to liner. One of the major drawbacks of selecting HDPE liner is frequent reporting of liners being breached (Montague, 2006). Engineered low lying landfill is a new concept and accepted by the international scientific community as being a novel approach to design landfills (Basnayake et al., 2005). In order to implement such a conception, a research was conducted on developing a liner suitable for landfill bioreactors at the University of Peradeniya. It consisted of a composite liner of clayey soil-waste polyethylene-clayey soil (Gunarathne et al., 2007).

As mentioned above, soil filling was found to be expensive and a compromise was reached to fill the quarry with old waste much above the water table. Thus, a firm ground built above this maximum level for the compactor to travel on. The height of the fill should be $1.6 \mathrm{~m}$ above the datum to allow for secondary settlement of $1.5 \mathrm{~m}$ over the next three years. Above this layer, the developed composite liner constructed to reduce deep percolation of the leachate and thus there is a need for a 'stilling well' to extract excess leachate for treatment in constructed wetland or by recirculation. Otherwise, the excess leachate becomes a problem. 
Effectively, there will be two liners, one to prevent pollution of leachate generated from the old filled waste as the area close to the houses is highly permeable according to the geological survey and the other for preventing pollution of leachate generated from raw wastes. Due to the uneven old waste settlement, there is a possibility to breach the composite liner on the old waste filled area. The advantage of the composite liner is, unlike HDPE liners it could heal the breaching by itself. Even if there is a leak of leachate, the second composite liner at the bottom of the fill will curtail the contamination. Over number of years, the old wastes will decompose at a very slow rate to produce a material similar to tropical peat that will have a high content of inorganic. The Fig. 2 is a typical cross section of the filling with old and new wastes. There will be gas vents constructed to allow escape of gas from the old wastes.

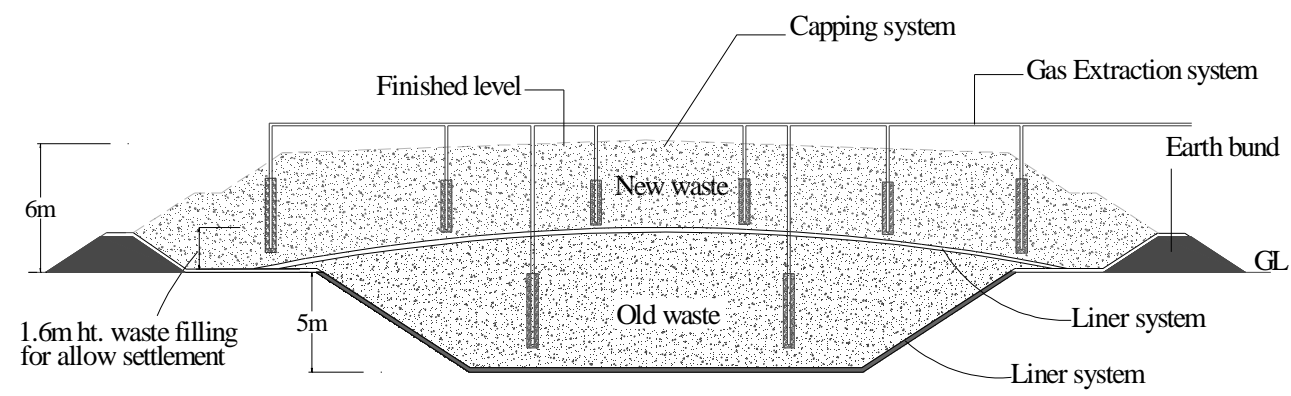

\section{Fig. 2. A typical cross section of landfill bioreactor}

\section{Landfill bioreactor (Biocells)}

The placement of new wastes is above the datum to a height of $6 \mathrm{~m}$. The expected gas generation is $5 \mathrm{~L} / \mathrm{h} /$ tonne of wastes and each cell will produce gas for a period of three years. The produced gas will be collected through collection network. Once the gas is exhausted, the remaining wastes excavated and processed to produce residual derived fuel (RDF).

\section{Extent, capacity and life span of the landfill}

The designed extent of the landfill bioreactor is amounting to 4 hectares. The estimated quantum of old wastes in the quarry is 6600 tonnes, which is sufficient to fill the low-lying part of the quarry. The filling of raw wastes is above the second liner base. The width of the landfill is $55 \mathrm{~m}$ and the total extent is $11,115 \mathrm{~m}^{2}$. The design capacity is 38,300 tonnes over a period of three years with an average disposal of 35 tonnes/day. Once the gas exhausts after extracting over three years, the mining operation of the first biocell is required. Only after the mining operation is over, the land is available for refilling. Thus, more lands are required for establishing biocells sufficient for at least one year for developing a sustainable system. Therefore, it is essential to find fill materials for developing another landfill bioreactor on the proposed quarry area with required extent of $3,700 \mathrm{~m}^{2}$. The design capacity of this landfill bioreactor is 12,800 tonnes.

\section{Leachate collection system}

A threshold value of $3500 \mathrm{mg} / \mathrm{L}$ is an acceptable value for maintaining leachate within the old fill materials. Then, the necessity for removal of leachate will arise if leachate exceeds the threshold value for decomposed materials. In addition, treatment is required, when the 
leachate level inside the old waste filling exceeds the datum, thus four number of stilling wells will be used to remove excess leachate from the old wastes to avoid spilling of leachate.

The above ground landfill bioreactor will consist of a network of single perforated PVC drainpipes embedded in an protection envelop of aggregate and geonet, leading to the second set of six leachate (stilling) wells. They will be independent and separate to the wells constructed to control the leacahte accumulations in the base of the landfill.

\section{Water balance in the landfill bioreactor and leachate treatment}

The biocells with leachate recirculation is the most effective method of treating high concentrated leachate. It is necessary to dilute the leachate during the application. The rainwater or irrigations dilute the leachate to acceptable levels for effective anaerobic digestion in the biocell (Chugh et al., 1998). The design is to have a leachate head of one meter to allow for internal treatment while having adequate reservoir for supplying moisture of $1.6 \mathrm{~m} / \mathrm{m}^{2}$ per annum for evapo-transpiration, which is on an average at the rate of 8 $\mathrm{mm} /$ day. The total irrigation requirement is $12.5 \mathrm{~m}^{3} / \mathrm{hr}$ over duration of 8 hours. In addition, the predicted deep percolation losses through the composite biofilm liner are $120 \mathrm{~m}^{3} /$ day. In effect, groundwater is required for irrigating the biocells and supplying sufficient water for diluting the leachate, amounting to $27.5 \mathrm{~m}^{3} / \mathrm{h}$. Then, the total requirement is $220 \mathrm{~m}^{3} /$ day for the effective extent of the landfill of $11,115 \mathrm{~m}^{2}$. The ground water depletion is $0.89 \mathrm{~m}$ of free water surface and approximated to $1.5 \mathrm{~m}$ within sandy soil that is prevailing in the subterrain.

The allowable leachate head inside the landfill body for a maximum storm of $600 \mathrm{~mm} / \mathrm{hr}$ over a period of 1 hour or accumulated quantity of $800 \mathrm{~mm}$ in a day is the main criterion for the design of leachate treatment system. The usual leachate generations estimated at 125 $\mathrm{m}^{3} /$ day, considering the entire landfill. Usually, $300 \mathrm{~mm}$ retention of leachate head is allowed to keep the landfill from drying out. Thus, $300 \mathrm{~mm}$ of leachate require treatment over a period of four months or $28 \mathrm{~m}^{3} /$ day. This would require a constructed wetland of 56 $\mathrm{m}^{2}$ with an effective depth of $0.5 \mathrm{~m}$ or actual $1 \mathrm{~m}$ to bring the BOD lower than $400 \mathrm{mg} / \mathrm{L}$ with in a day. The conceptual design of constructed wetland is shown in Fig. 3. Old wastes too will generate leachate and it may require treatment. The planning is to treat the leachate during the dry period when the constructed wetland is available and free from treating fresh leachate generated from raw wastes during the rainy period. 

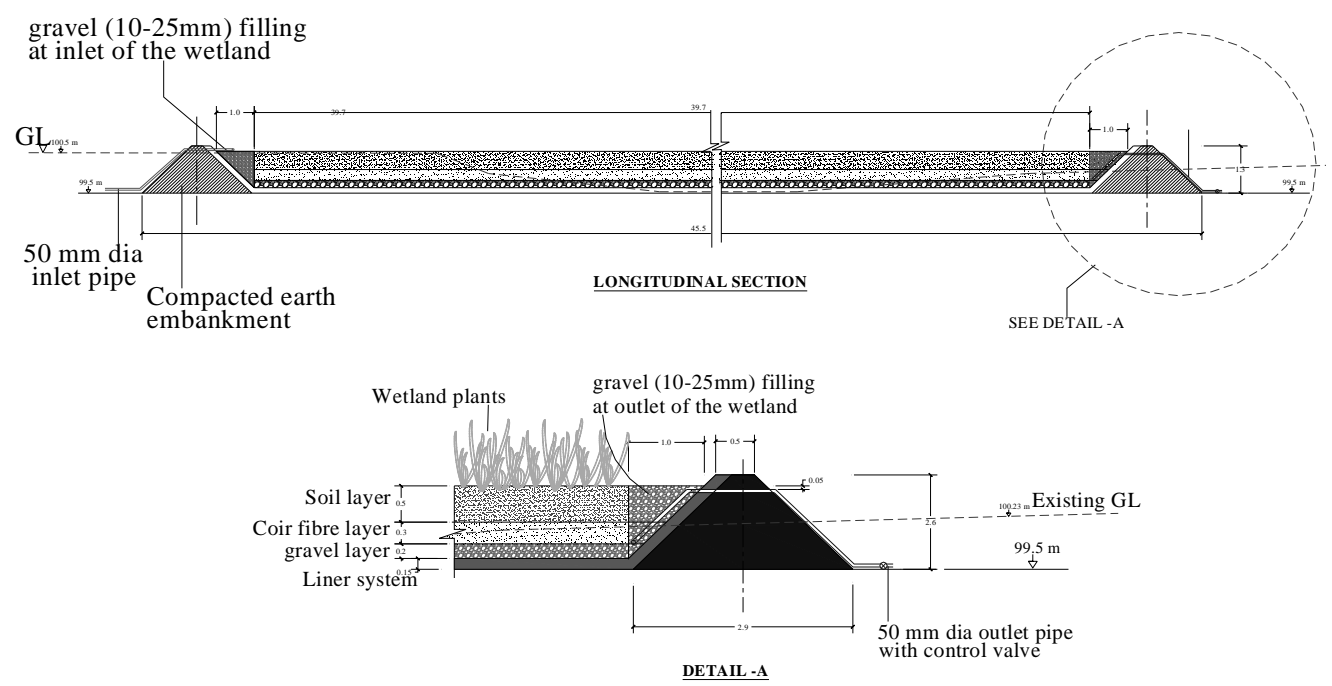

Fig. 3. Conceptual design of constructed wetland design of surface water drain system

All of the exposed surfaces of the landmass will be grassed or covered with vegetation and will have a slope towards the road. There will be two surface drains along the road end of the site that slope towards the middle. The construction of the drain is to be along the inner side of the fence on the periphery of the land. All of the water draining from the roofs and other surfaces will go through these surface drains on to the other side through a new culvert to be constructed. In addition, the excess overflow from the large pond channeled through a drain connected to the same culvert. If recommendation is for an average velocity of $2 \mathrm{~m} / \mathrm{s}$ to prevent scouring, the diameter of the culvert should be $0.8 \mathrm{~m}$.

\section{CONCLISIONS}

The present practices of disposing waste by the BMC are not acceptable and it is causing environmental issues and affecting the health of the population and thus, lowering socioeconomic status of Batticaloa Municipal area. Therefore, the intension of the project is to rehabilitate the dumpsite quarry with challenging designs. The most important design criterion is to lay a composite biofilm liner to curtail leachete and gaseous emissions in order to mitigate the environmental impacts. The locally developed liner is the best solution for curtailing the leachate even under submerged conditions. Thus, constructing an aboveground landfill bioreactor adequate for three years capacity is possible to be built on the filling of old wastes existing in the site, since the importation of soil to the land is costly. However, the rate of settlement of old waste fill is an important design criterion to prevent the aboveground landfill with three lifts to undergo submergence. The design is such that the storm water will not inundate the site and a direct drainage system independent from the surrounding system is proposed.

In the dry conditions and to maintain optimum moisture in the landfill bioreactor, the total water requirement, including irrigation is depending on the water storage in the old fill underneath the landfill bioreactor and the pond waters to prevent exploitation of scarce 
groundwater in the area. During the rainy periods, the design is for treating excess leachate from the landfill bioreactor in a constructed wetland. These efforts will rehabilitate and convert the dumpsite quarry to a landfill bioreactor for sustainable management of solid waste in BMC limits.

\section{ACKNOWLEDGEMENTS}

The authors are grateful to the BMC staff, NECCDEP project officials, and EML consultants for their concerns and the dedications towards the success of the project.

\section{REFERENCES}

Basnayake B.F.A., Chiemchaisri C. and Mowjood M.I.M. (2005). Solid wastes arise from the Asian tsunami disaster and their rehabilitation activities: Case study of affected coastal belts in Sri Lanka and Thailand. Presented at Tenth International Waste Management and Landfill Symposium - Sardinia 3-7 October 2005 at Santa Margherita di Pula (Cagliari) Sardinia - Italy.

Chugh S., Clarke W., Pullammanappallil P. and Rudolph V., (1998). Effect of recirculated leachate volume on MSW degradation. Waste Magt. Res. 16(6): 564-573.

Gunarathna H.A.Y.R., Kapukotuwa A.S.B., Karunarathna A.K. and Basnayake B.F.A., (2007). Construction and evaluation of a low cost, wasted polyethylene based liner for small landfills. Proceedings International Conference on Solid Waste Management, Chennai, India, 5-7 September, 2007.

Gunawardana, E.G.W., Shimada, S., Basnayake, B.F.A. and I. Tomoko. (2008). Evaluation of microbial dynamic and organic waste degradation in municipal solid waste landfills in Sri Lanka. Presented at APLAS international symposium, Japan.

Montague T., (2006). What will the PDC landfill Mean for Peoria's Future?: A costly cleanup. Environmental Research Foundation, 6513 N. Christiana Ave, Lincolnwood, IL 60712, Chicago, IL.

Qian X., Koerner R.M. and Gray D.H. (2002). Geotechnical aspects of landfill design and construction, Prentice-Hall Inc., Upper Saddle River, New Jersey 07458.

Shariatmadari N. and Mansouri A., (2008). Monitoring the Landfill Settlement, Case Study: Tehran Sanitary Landfill. Available online at http://lib.hpu.edu.cn/comp_meeting/

Accessed on 10-06-2009. 